\title{
Multilayer cattle farming: a new dimension towards waste management and environmental sustainability in Bangladesh
}

\author{
S.K. Sarkar ${ }^{1 *}$ and M.K.Uddin ${ }^{2}$ \\ ${ }^{1}$ Rural Development Academy (RDA), Bogra-5842, Bangladesh. ${ }^{2}$ Jahangirnagar University, \\ Savar-1341, Dhaka, Bangladesh.
}

\begin{abstract}
An on-station study was conducted at demonstration farm of Rural Development Academy (RDA) Bogra, Bangladesh with objectives to determine the impact of multilayer (two storied) cattle farming on food security for achieving economical and environmental sustainability. A two storied shed for cattle rearing were built with 10:1 slope for easy drainage and disposal of urine, faeces, wash water, feed refusals to a biogas plant directly for anaerobic digestion. About $70-80 \%$ waste materials was automatically and the rest amount was transferred manually. Per annum total waste 787.67 tons was used and produced 28356 $\mathrm{m}^{3}$ biogas and 157.53 tons of organic manure. Gross return of Tk. $24,61,272$ and gross profit of Tk. 1145672 was made on a capital investment for Tk. 13,15,600. The benefit cost ratio (BCR) found 1:1.87. Compared to conventional, multilayer farming significantly higher amount of fresh manure was collected. In conventional farming, on an average $39.4 \%$ of manure is lost due to rain and flood caused contamination of water and threat to public health. The analysis of per day income from a cow was significantly ( $\mathrm{p}<0.01)$ higher in multilayer farming system compare to conventional system. The average income from manure was Tk. 24.14 and Tk. $4.62 / \mathrm{cow}$, respectively. Thus, it may be concluded that multilayer cattle farming may be more profitable and effective for waste processing, reduction of pollution and sustainable development of environment.
\end{abstract}

(Key words: Multilayer, cattle farming, waste management, environment, sustainability).

\section{Introduction}

There is no practice of improved livestock manure management system in Bangladesh to address sustainable environment except the traditional management system which causes a lot of problems especially water pollution, un-hygienic and hazard to public health as well as to the farm animals. One of the most important outputs of the Earth Summit (United Nations Conference on Environment and Development) in 1992 was
Agenda 21: which includes an action plan for the twenty-first century, elaborating strategies and integrated programme measures to halt and reverse the effects of environmental degradation and to promote environmentally sound and sustainable development in all countries (UNCED, 1992). Active and strengthened waste re-uses and recycling systems were also recognized in Agenda 21. The consensus on sustainable development emerged from the Earth Summit required to be transformed *Corresponding author: samirda@yahoo.com 
into actions by engaging in a period of decentralized experimentation (Brugmann, 1994).

Multilevel cattle herd farming may play a vital role for livestock production through improved manure management and it may play an important role on sustainability of the environment, of managing noxious odors from livestock farming and reducing GHGs (green house gases; Sarkar and Uddin, 2013). Livestock waste management at farm and individual level in Bangladesh is identified as one of the key environmental issues causing water contamination and health sanitation deterioration with water borne diseases (Gofran, 2007). These wastes can be managed and converted to resources following the model "Asset Based Community '. Development (ABCD) "developed by Sarkar \& Uddin 2011.

The multilayer cattle farming system in RDA campus, Bogra, Bangladesh is one of the examples of waste collection with recycling of organic waste, as the suitable options for environmentally sound solution to overcome waste management problems particularly in livestock sector. Thus, the present study was undertaken with the objectives as follows:

i. To identify the situations of multilayer housing of cattle rear as a model for better solid waste management; and

ii. To determine the impact of improved livestock manure management and it's value related to livestock farming towards environmental sustainability.

\section{Materials and Methods}

\section{Data collection}

Rural Development Academy (RDA), Bogra cattle farm is situated in the northern part of Bangladesh and reared cattle in multilevel housing since 2002. Monthly farm waste production of cattle, poultry, sheep and buffalo were collected for a period of one year (2013-14) from the secondary source of RDA Farm Office. The household waste production data including cafeteria and guest house were collected from the community biogas project office of RDA. The researcher also took the support of FGD, KI and direct observation with checklist to fulfill required information to complete this paper. The secondary data were collected during the period of January-May 2015. Apart from these 10 conventional dairy farms were also considered for data collection from Sirajgonj, Bogra and Gaibandha districts on the basis of ex-ante information. The average herd size is relatively higher and consists of proportionately more crossbred cows and farms are located between rural and peri-urban areas (Uddin et. al., 2011).

\section{Design of multilayer cattle shed}

RuraI Development Academy, Bogra has started rearing dairy cattle on two storied cattle shed system keeping milch \& dry cows as on ground floor ( $1^{\text {st }}$ layer) and calves (first floor) as on the $2^{\text {nd }}$ layer using rubber mat for both layers to provide comfort as well as for scoping the availability of comprehensive waste collection to be used as input materials of biogas plant. The shed were built with 10:1 slope for easy drainage 
and disposal of urine, faeces, wash water, feed refusals to a biogas plant directly for anaerobic digestion. Following application of a mixture of urine, faeces, flash water with feed residual produced by 130 cattle heads connected to the ground pipeline for discharging to biogas plant for anaerobic digestion to get biogas and bio-slurry automatically with gravitation flow. This two floors type of cattle shed was subjected to a constant airflow through crossventilation and sufficient sunshine to keep the floor dry and clean. With this system about $70-80 \%$ waste materials transferred automatically and the rest amount was transferred manually to biogas digester (Fig. 1).

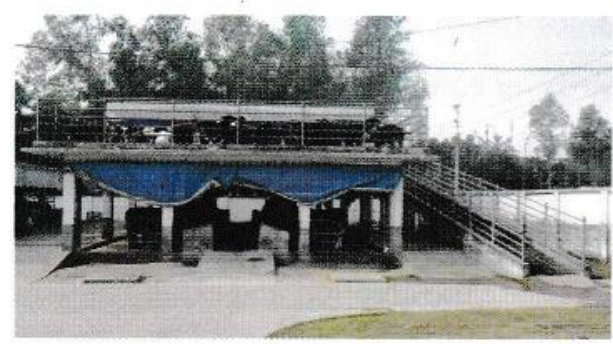

Fig.1: Multilayer cattle shed at RDA

\section{Collection of waste materials}

\section{Cowdung}

The cowdung was collected from the cattle rearing multilayer system automatically. The quantity of cowdung (dry basis) was calculated by multiplying the cowdung production per head per year and the number of cattle reared in the farm.

\section{Goat faeces}

The dry biomass obtained from goat faeces per head in the study area was also estimated by same method used in cattle. The goat faeces quantity per head per year was found $19.21 \mathrm{~kg}$ in the study area which was almost similar to the finding (dry matter basis) per head per year was estimated at $19.25 \mathrm{~kg}$ (Shahjalal et al,. 1997).

\section{Poultry droppings}

According to Uddin (1991) average per head poultry dropping production was estimated at $10.95 \mathrm{~kg}$ on dry matter basis but in the study area it was $11.22 \mathrm{~kg}$ per bird per year.

Total dry matter (DM) from livestock used as input for the biogas plant was calculated by the following formula:

$$
W_{c d}=\frac{\sum_{i=1}^{n} P_{c r}(i) x f_{c r}(i)+G_{d p}(i) x F_{d p}(i)+P_{d p} x F_{d p}}{\sum_{i=1}^{n} C_{d p}+G_{d p}+P_{d p}}
$$

Where,

$\mathrm{W}_{\mathrm{cd}}=$ Total cow dung used as input of biogas plant by the community, ton

$\mathrm{C}_{\mathrm{dp}}=$ Production of dried cow dung of (i) family, ton

$\mathrm{G}_{\mathrm{dp}}=$ Production of dried goat faeces of (i) family, ton

$\mathrm{P}_{\mathrm{dp}}=$ Production of dried poultry droppings of (i) family, ton

$F_{d p}(i)=$ Percentage of dry dung used as input by (i) family, ton $\mathrm{n}=$ Number of family of a community.

\section{Total fuel consumption for cooking}

Total fuel consumption for cooking was calculated by using the following formula:

$$
T_{F c o n}=\sum_{i=1}^{n} W_{\text {fuel }}(i) x H_{\text {fuel }}(i)
$$


Where,

$T_{F c o n}=$ Total fuel consumption for

cooking, $\mathrm{kg} /$ year.

$W_{\text {fuel }(i)}=$ Weight of (i) fuel for cooking,

$\mathrm{kg} /$ year.

$H_{\text {fiel }}(i)=$ Heating value of (i) fuel, $\mathrm{kJ} / \mathrm{kg}$.

$\mathrm{n}=$ Number of fuel type.

\section{Statistical analysis}

All the data were computed in Excel program and the processed data were subjected to analyze statistically using student t-test.

\section{Results and Discussion}

\section{Multilayer cattle housing and RDA's experiences}

Bangladesh is one of the countries concerning cattle production since ancient time, with a significant potential to improve cattle waste management. At present, most of the cattle waste is stored/dumped in open space, exposed to sun light and rain fed, which leads to emissions of methane 711.34 $\mathrm{kg}$ CH4Yr-1 from 131 heads cattle and reduction in nutritional value of the cattle waste and a great source of environmental pollution. This emission may be turned into "zero" by converting and using biogas as renewable energy source (Table 4). It is noted that, the average methane emission factor from different manure management system was estimated to be $6.77,6.41,5.42$, 0.203 and $0.024 \mathrm{KgCH} 4 /$ head, respectively, of dairy or other cattle, buffalo, small ruminant and poultry. This calculates to be annual total methane emission of $142.40 \mathrm{Gg}$,
$2.47 \mathrm{Gg}, 2.71 \mathrm{Gg}$ and $2.50 \mathrm{Gg}$, respectively, from the total number of farm animals and poultry. In the study area average cattle heads found to be 13.1 per commercial farm and 1.6 for subsistence level, which is decreasing trends compare to national average per household 15 animals in case of commercial and for subsistence level average per household 2.0 animals thus livestock farming affects extent of manure $\mathrm{CH}_{4}$ emission (Agricultural census, 2008).

Rural Development Academy, Bogra has successfully carried out experimentation on solid waste management in her campus on community participation and combining with two storied cattle housing on station at demonstration farm.

Multilayer cattle farming technology offers a potential for boosting up rural productivity and changing livelihoods and stakeholder participation to the policy process may help to facilitate the creation and establishment of a successful livestock sector. The challenge is therefore to improve stakeholders' participation to the policy-making process and ensure successful establishment of a waste management strategy as well as enhancing livestock sector in Bangladesh.

\section{Organic manure as Palli Jaibo Sar}

RDA running about 112 community based biogas plants over the country which is proved as environment friendly and economically feasible including one multistoried cattle shed for on station experimental purpose at RDA, Bogra under action research projects $(2009-2015)$. The average production from 112 biogas plants is 
about 40-50 tons/day. Bio-slurry contents $100 \%$ organic fertilizer that has been proven as the most suitable fertilizer as well as may supplements chemical fertilizers in Bangladesh. As one of the marketing \& extension partners, the private company ACI has vast network engaged to promote the use of bio-slurry as organic fertilizer with the brand name ("Palli Jaibo Sar" Reg. No. M-604, Pack: $40 \mathrm{Kg}$.).

Palli Jaibo Sar has highly positive impact on the agricultural production in Bangladesh. Research findings confirmed that bio-slurry as an organic fertilizer has positively affected crops by increasing the yields. Furthermore, bio-slurry has vital role on restoring soil organic matters which are at alarmingly low levels (less than $1 \%$ to some regions) in Bangladesh. A proper fertility management of soil as seen very critical. Farmers used mostly chemical fertilizers (under/over doses of certain nutrients) in their land instead of organic fertilizers. To conserve and boost up the soil health farmers need motivation and to convert locally available organic resources into community biogas plants to capture multidimensional benefits such as- biogas for cooking \& electricity generation, organic fertilizers and safe water supply with various scopes of having friendly environment, employment generation and overall supports etc. This organic fertilizer would certainly put a vital role to reduce the quantity of using chemical fertilizers and would help to get sustainable agricultural practice in Bangladesh.
At present, a total number of 63 households (4 storied building), guest house, DG's bungalow have been connected under biogas facilities. Moreover a 5 KVA generator is being operated using biogas and a portion of RDA demonstration farm premises has come under gas-electricity. The slurry (fermented cow dung \& kitchen waste) produced from biogas plant are processed as organic manure and sold at market through Advanced Chernical Industries Limited (ACI) in a branded name of "Palli Joibo Sar" (Rural Organic Manure) after mitigating local demand which leads to a great contribution for soil fertility and this study is fully agreement with study conducted by Sarkar et al. (2011).

The month wise daily average inputs and mixing ratio of waste materials supplied to RDA Farm are presented in Table (1 \&2).

As there is no availability of gridline natural gas, most of the respondents depend on wood fuel for cooking. Due to insufficiency of natural forests the users need to collect fuel wood from the local market by paying higher prices i.e. price hiking for wood fuel is a problem for the study area. The major sources of biogas production feeding materials are from livestock waste $(87 \%)$, poultry droppings $(8 \%)$, kitchen waste $(4 \%)$ and others (1\%) etc. (Fig. 2).

\section{Economic benefit}

The yearly income and expenditure of RDA farm in consideration waste management are given in Table 3. During one year (2014) total waste amounted 787.67 tons was managed which produced $28356 \mathrm{~m}^{3}$ biogas 
Table 1. Daily average feeding to the Biogas Plant by waste category

\begin{tabular}{lccccc}
\hline \multirow{2}{*}{ Month } & \multicolumn{5}{c}{ Amount (kg) of feeding materials used /day } \\
\cline { 2 - 6 } & Cow dung & $\begin{array}{c}\text { Poultry } \\
\text { droppings }\end{array}$ & Kitchen waste & Others & Total \\
\hline January & 1357 & 140 & 84 & 15 & 1596 \\
February & 1318 & 166 & 97 & 19 & 1600 \\
Mareh & 1533 & 182 & 85 & 21 & 1821 \\
April & 2469 & 192 & 64 & 26 & 2751 \\
May & 2536 & 234 & 103 & 28 & 2901 \\
June & 2847 & 203 & 74 & 35 & 3159 \\
July & 1935 & 202 & 61 & 28 & 2226 \\
August & 1576 & 203 & 74 & 14 & 1867 \\
September & 1644 & 156 & 77 & 21 & 1898 \\
October & 1706 & 131 & 86 & 17 & 1940 \\
November & 1765 & 158 & 95 & 28 & 2046 \\
December & 1770 & 180 & 108 & 38 & 2096 \\
Average & 1871 & 179 & 84 & 24 & 2158 \\
\hline
\end{tabular}

Table 2. Raw materials supplied to the biogas plant by percentage, ratio \& price per $(\mathrm{kg})$ at RDA Farm, Sherpur, Bogra.

\begin{tabular}{|c|c|c|c|c|c|}
\hline \multirow{2}{*}{ Item } & \multicolumn{5}{|c|}{ Category of raw materials } \\
\hline & Cowdung & $\begin{array}{c}\text { Poultry } \\
\text { droppings }\end{array}$ & $\begin{array}{l}\text { Kitchen } \\
\text { waste }\end{array}$ & Other & Comment \\
\hline Feeding to biogas plant (\%) & 87 & 8 & $\overline{4}$ & 1 & $\begin{array}{l}\text { Depends on } \\
\text { availability }\end{array}$ \\
\hline $\begin{array}{l}\text { Feeding to biogas plant } \\
\text { (water: material) }\end{array}$ & $1: 1$ & $1: 2$ & $1: 0.5$ & $1: 1$ & $\begin{array}{l}\text { Depends on } \\
\text { raw materials }\end{array}$ \\
\hline Average price Tk. per $(\mathrm{kg})$ & 0.50 & 0.50 & 1.00 & 0.50 & $\begin{array}{c}\text { Including carrying } \\
\text { Tk. } 0.62 / \mathrm{kg} .\end{array}$ \\
\hline
\end{tabular}

and 157.53 tons of organic manure respectively through investing Tk. 1315600 and earned Tk. 2461272, thus the net profit captured Tk. 1145672 by this system. The produced biogas used for cooking by 63 households and electricity generation purposes. The benefit cost ratio (BCR) found $1: 1.87$, which was very much satisfactory particularly the waste managed as resources for livestock sector.
The net income from biogas supply secured Tk. 375600 , electricity supply Tk. 22600 and water supply Tk. 48600 , beef fattening Tk. 26000. The income generated from organic manure and biogas supply was Tk. 672872 and Tk. 375600 respectively. Finally deducting all expenditure (Tk. 1315600) from the gross income (Tk. 2461272) the net profit of the farm captured Tk. 1145672. So the dairy farm stands earlier identified as 
Table 3. Major item wise yearly income \& expenditure of RDA Farm's biogas plant

\begin{tabular}{|c|c|c|c|c|c|c|c|c|}
\hline \multirow[t]{2}{*}{ Item } & \multicolumn{4}{|c|}{ Yearly expenditure (Tk.) } & \multicolumn{4}{|c|}{ Yearlyincome (Tk.) } \\
\hline & Input & Labor & Other & Total & Irrigation & Farm & Total & $\begin{array}{c}\text { Net } \\
\text { income }\end{array}$ \\
\hline Deep tube well & $\begin{array}{c}24000 \\
\text { (1) }\end{array}$ & $\begin{array}{c}72000 \\
\text { (1) }\end{array}$ & 3000 & 99000 & $\begin{array}{c}75600 \\
(63)\end{array}$ & $\begin{array}{c}72000 \\
(3)\end{array}$ & 147600 & 48600 \\
\hline $\begin{array}{l}\text { Biogas } \\
\text { generator }\end{array}$ & $\begin{array}{l}12000 \\
(1)\end{array}$ & $\begin{array}{c}72000 \\
(1)\end{array}$ & 5000 & 89000 & $\begin{array}{c}75600 \\
(63)\end{array}$ & $\begin{array}{c}36000 \\
(3)\end{array}$ & 111600 & 22600 \\
\hline Biogas supply & 12000 & $\begin{array}{c}72000 \\
(1)\end{array}$ & 6000 & 90000 & (63) & $\begin{array}{l}12000 \\
(1)\end{array}$ & 465600 & 375600 \\
\hline $\begin{array}{l}\text { Organic } \\
\text { fertilizer }\end{array}$ & 409588 & $\begin{array}{c}151200 \\
(397)\end{array}$ & 6612 & 587400 & - & 1260272 & 1260272 & 672872 \\
\hline Beef fattening & $\begin{array}{c}372200 \\
(22)\end{array}$ & $\begin{array}{c}72000 \\
\text { (1) }\end{array}$ & 6000 & 450200 & - & $\begin{array}{c}476200 \\
\text { (1) }\end{array}$ & 476200 & 26000 \\
\hline Total & & & & 1315600 & & & 2461272 & 1145672 \\
\hline
\end{tabular}

Figures in the parenthesis indicate number of user; $1 \mathrm{USD}=\mathrm{Tk} .80 .00$

breakeven point on the basis of milk selling, has graduated as profitable farm by introduction of multilayer cattle rearing in combination with biogas plant.

\section{Economics of multilayer manure manage- ment vs conventional system}

The manure management systems in conventional and improved multilayer farm are presented in Table 4 . The average production of fresh manure $(\mathrm{p}<0.05)$, collection $(p<0.01)$, dried manure $(p<0.01)$ production per cow were significantly higher in improved multilayer cattle farming compare to that of conventional system and the corresponding values were 14.4, 17.0, 4.3 and $10.3,9.1,1.52 \mathrm{~kg}$, respectively. The higher production and collection of manure in improved multilayer farming compare to conventional system was due to improve rearing, housing, collection system and also better husbandry practices followed by the farmers' in the study area. In conventional farming, farmers usually having a traditional pit nearby cattle shed to store manure. In conventional system, on an average $39.4 \%$ of manure was lost or swiping away due to rain and flood which affect not only loss of manure but also root cause of water contamination and water borne diseases with noxious odor and threat to the public health. The utilization of livestock manure for production of biogas either through using multilayer farming or community based biogas plants (CBP) helps improved management of livestock waste through reduction of solid storage and burned fuel used $(66.5 \%)$ in the study area. Reduction of GHG, noxious fume inhalation \& women hours save in an average $2.3 \mathrm{hrs} /$ farm for household keeping and cooking and the improvement of household health and hygiene are secondary benefits, in addition to clean air production. In RDA, multilayer 
Table 4: Manure management system under conventional and multilayer farming system

\begin{tabular}{|c|c|c|c|c|c|c|c|c|}
\hline \multirow[t]{2}{*}{ Variables } & \multicolumn{3}{|c|}{ Conventional } & \multirow[t]{2}{*}{ Multilayer } & \multirow[t]{2}{*}{ t-value } & \multirow[t]{2}{*}{ p-value } & \multirow[t]{2}{*}{ Comments } & \multirow{2}{*}{$\begin{array}{l}\text { Level of } \\
\text { sig. }\end{array}$} \\
\hline & Mean & SD & $\mathrm{CV}$ & & & & & \\
\hline $\begin{array}{l}\text { Manure production } \\
(\mathrm{kg} ; \text { cow/day) }\end{array}$ & 10.3 & 2.50 & 24.24 & 14.4 & $\overline{3.05}$ & 0.0111 & Sig. & 0.05 \\
\hline $\begin{array}{l}\text { Dried manure } \\
\text { production }(\mathrm{kg} \\
\text { cow/day) }\end{array}$ & 1.52 & 0.37 & 24.38 & 4.3 & 7.15 & 0.0000 & Sig. & 0.01 \\
\hline $\begin{array}{l}\text { Manure collection } \\
\text { from pit (kg;cow) }\end{array}$ & 5.55 & 1.68 & 30.34 & 16.8 & 6.37 & 0.0001 & Sig. & 0.01 \\
\hline Manure loss (\%) & 39.39 & 21.97 & 55.80 & 0 & 1.71 & 0.0952 & Sig. & 0.1 \\
\hline Labor per cattle (no.) & 0.16 & 0.06 & 36.90 & 0.05 & 1.85 & 0.0768 & Sig. & 0.1 \\
\hline $\begin{array}{l}\text { Time savings (hour; } \\
\text { women) }\end{array}$ & 2.30 & 0.49 & 21.31 & 0 & 4.47 & 0.0011 & Sig. & 0.01 \\
\hline $\begin{array}{l}\text { Manure collection } \\
(\mathrm{Kg} ; \text { cow/day) }\end{array}$ & 9.1 & 2.23 & 24.54 & 17 & 3.37 & 0.0065 & Sig. & 0.01 \\
\hline $\begin{array}{l}\text { Milk Production } \\
\text { (Litre;cow/day) }\end{array}$ & 6.35 & 1.10 & 17.33 & 12.7 & 5.50 & 0.0002 & Sig. & 0.01 \\
\hline Burnt fuel as cake (\%) & 66.5 & 6.06 & 9.11 & 0 & 10.46 & 0.0000 & Sig. & 0.01 \\
\hline $\begin{array}{l}\text { Disease prevalence } \\
\% ; \text { YYear) }\end{array}$ & 41.3 & 17.11 & 41.42 & 6 & 1.97 & 0.0648 & Sig. & 0.1 \\
\hline $\begin{array}{l}\text { Land requirement } \\
\text { (sqm; cow) }\end{array}$ & 4.80 & 1.03 & 21.50 & 1.62 & 2.94 & 0.0134 & Sig. & 0.05 \\
\hline $\begin{array}{l}\text { Biogas production } \\
\text { (m3; farm/day) }\end{array}$ & 0 & 0 & 0 & 110 & - & - & - & - \\
\hline $\begin{array}{l}\text { Income from manure } \\
\text { (Tk./cow) }\end{array}$ & 4.62 & 1.04 & 22.58 & 24.14 & 17.84 & 0.0000 & Sig. & 0.01 \\
\hline
\end{tabular}

cattle farming system could manage in an average per day production of biogas 110 $\mathrm{m}^{3}$, allowing space $1.62 \mathrm{~m}^{2} /$ cow, waste collection $16.8 \mathrm{~kg} /$ cattle, manure production $4.3 \mathrm{~kg} /$ cattle, milk production 12.7 litters/ cow respectively. On the other hand, in conventional farming system could manage in an average per day production of biogas " 0 " $\mathrm{m}^{3}$, allowing space $4.80 \mathrm{~m}^{2} / \mathrm{cow}$, waste collection $5.55 \mathrm{~kg} /$ cattle, manure production $1.52 \mathrm{~kg} /$ cattle, milk production 6.35 litters/cow respectively. For the conventional farming system analysis showed that significantly lower performances in case of biogas production, waste management as well as manure and milk production by using higher labor and family efforts for its diversified household and commercial uses through conversion into renewable energy significantly. The cost and benefit analysis indicated that, per day income from a cow was significantly higher $(p<0.01)$ in improved multilayer farming system compare to conventional system and the respective income was Tk. 24.14 and Tk. 4.62 , respectively. 


\section{Further scope for sustainable waste management}

As there is no availability of natural gas, most of the respondents depend on LPG for cooking. The main sources of biogas production materials are livestock waste $(87 \%)$, poultry droppings $(8 \%)$, kitchen waste (4\%) and others (1\%) etc. (Fig 2). marshy lands due to rain or floods (Sarkar et.al., 2013), This great loss may combat through a community approach of livestock rearing in common cattle sheds with common benefit sharing having connection to need based biogas plants for waste management and to capture multidimensional benefits of livestock raising.

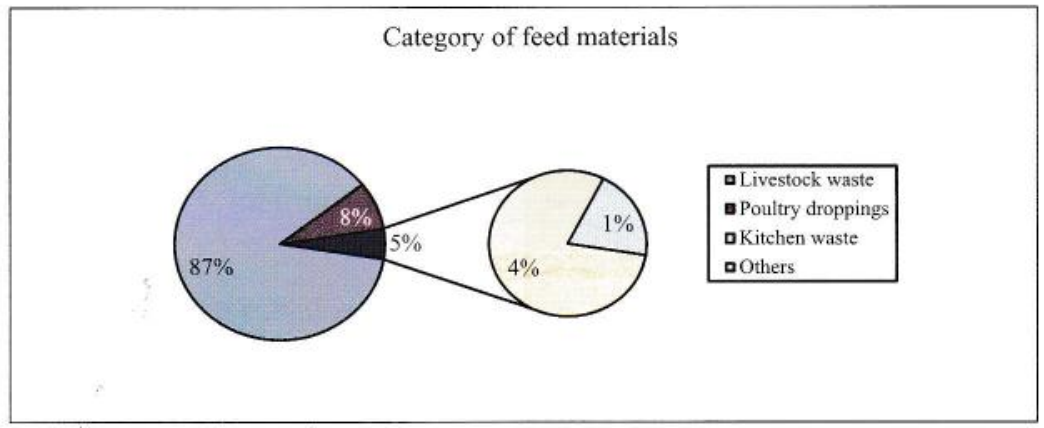

Figure 2: Category wise feed materials supply to the biogas plant

Almost about $80 \%$ waste in solids, semi-solid or in liquid form automatically goes to biogas digester connected through underground pipelines thus the labor cost could reduced in case of multilayer housing as well as saves lands for individual level of farming. As for example, at the village in tradition mostly cattle are reared at individual farmer level with particular cattle shed and keeping a pit of land for preparing compost fertilizer. This traditional system is not viable enough to conserve all the degradable wastes produced by the cattle and from farmers' household because of open dumping. Research findings show that about $40-90 \%$ (Seasonal variation) wastes washed out and contamination occurs mainly to the surrounding ponds, rivers, beel, haur or other
These cattle sheds should be multistoried with especial facilities for waste management in an underground pipelines network connected to biogas plant like as RDA cattle farm.

In traditional cattle rearing system at village level, major problems to run community biogas as accumulation, handle and manage the degradable waste produced over the village. To overcome the difficulties of waste accumulation in addition to incorporate the production of energy from waste resources for cooking, lighting and using renewable energy (Biogas) for lifting and supply of water multilayer cattle farming of community approach model may be the best option in Bangladesh. The benefits of this option are also multidimensional of 
which included both in quantitative and qualitative. The piece of study is the success experience of using multilayer cattle farming at RDA farm in multi-dimensional sectors of rural development in efficient way.

\section{Conclusion}

Multilayer cattle farming system may be considered as new approach for sustainable livestock production to ensure food security which creates new opportunities for managing waste effectively, reduction of pollution and sustainable development of environment.

This is the unique system for managing not only livestock waste but also having lots of usefulness e.g. land, labor and time saving for waste collection \& livestock rearing; maintain hygienic condition both for human and livestock, reduce diseases and water contamination, free from unpleasant odor from dairy barn, hazards free, feed materials for biogas plant opens new avenue of opportunities, wider scope for integration as means of livelihood change as well as the scenario of rural Bangladesh. Here is to be noted that this is the first time intervention of multilayer cattle farming practiced at RDA in Bangladesh. To harness the optimal benefits of livestock waste management and production, further in-depth action research is needed indeed to fulfill the following recommendations.

1. Multilayer cattle housing technology might be one of the best ways for meeting up food security in Bangladesh.
2. One village one building: both for human \& livestock which will create new opportunities for waste management with energy, organic fertilizer, socio-economic upliftment as well as friendly environment.

3. Expansion of community based multilayer livestock rearing program should be considered with utmost importance to enhance energy \& nutritional support, employment, land saving and sustainability of environment.

\section{References}

Brugmann, J. 1994. Who can deliver sustainability? Municipal reform and the sustainable development mandate. Third World Planning Review, 16(2), 129-146.

Gofran, M.A. 2007. Status of biogas technology in Bangladesh. The Daily Star: Wednesday, September 5, 2007.

Hossain, 2004. Food Security and Nutrition in Bangladesh: Progress and Deter- minants, a report prepared for FAO, Rome.

Sarkar S.K. and Uddin, M.K. 2011. Window of Opportunity: An Asset Based Approach to Community Development in Bangladesh. Journal of Developments in Sustainable Agriculture. 6:1-11 (2011): ISSN 1880-3016. AFRC, University of Tsukuba, Japan.

Shahjalal, M., Biswas, M.A.A. and Tareque, A.M.M. 1997. Effect of feeding Sesbania leaves on growth and nutrient utilization in goats. Bangladesh Journal of Animal Science, 26: $117-123$. 
Sarkar, S.K. and Uddin, M.K. 2013. Community based waste management and its utilization for sustainable environment. Bangladesh Journal of Animal Science, 42 (2): 165-173.

Sarkar, S.K. and Uddin, M.K. 2013. Converting Environment Friendly Waste into Wealth. Bangladesh Rural Development Studies. Vol. XVI No.1 (2013): 113-128.

Uddin, M.S. 1991. The effect of different dietary protein and energy levels on the performance of layer strain chicken in Bangladesh. PhD.Thesis, Department of Animal Nutrition, BAU, Mymensingh.
Uddin, M..M., Sultana,, M..N., Alqaisi, O., Ndambi, O.A., Hemme, T. and Peters, K.J. 2011. Milk production trends and dairy development in Bangladesh. Outlook on Agriculture Vol. 40 No. 3, pp. 263-271.

United Nations Conference on Environment and Development. 1992. Agenda 21: Program of Action for Sustainable Development. New York: UNCED. 